\title{
The Application of Contemporary Fiber Art in the Construction of Plastic Art Space
}

\author{
Guangyu Luo ${ }^{1, *}$ \\ ${ }^{I}$ Shanghai Academy of Fine Arts, Shanghai University, Shanghai 200040, China \\ ${ }^{*}$ Corresponding author. Email: 824677403@qq.com
}

\begin{abstract}
Fiber art has always been a kind of art form in people's life, and it is the product of life needs in the process of human development. While satisfying traditional fiber art's functionality and decorativeness, contemporary fiber art inherits traditional crafts and constantly innovates and develops and gradually integrates with the space environment. With the liberation of people's high dependence on material pursuit and the emphasis on the spiritual pursuit, the boundaries of the relationship between contemporary fiber art and space broke continuously through materials and technology innovation. Fiber art is no longer just a subsidiary of space, but a separate role in building space. In this paper, the actual case analysis of fiber art in the construction of space, materials, and technology supports the use of role in the development of urban status and prospects.
\end{abstract}

Keywords: Contemporary fiber art, Plastic art space, Material.

\section{INTRODUCTION}

The predecessor of fiber art is western old the tapestry art that gives priority to with braided technique. As a branch of the ancient handicraft, it has the most typical development characteristics of handicraft. In the second half of the 19th century, the Arts and Crafts Movement and the Art Nouveau Movement arose, practical mechanical combined with arts and crafts, technology combined with pure art, formed the fiber art new artistic language and aesthetic features. In contemporary fiber art performance on the basis of materials, technology and the diversification of forms, more emphasis on the fusion and unity with the space, and constantly to the humanistic trend.

\section{FIBER ART AND SPACE}

Fiber art is an art form that integrates practical function and aesthetic value. The characteristics of this art form is based on fiber as the carrier of visual expression, which mainly include the fiber materials, technology, design and other factors are used and reform. ${ }^{1}$ In addition, in the development

1. Zhao Na. Analysis of the Innovation of Contemporary Fiber Art Design Language [J]. Art Research, 2019 (06): 132-133. process of fiber art fusion of modern art concept and the latest achievements in modern textile technology, therefore it is regarded as an ancient and young art form. The inheritance of ancient fiber art techniques by contemporary fiber art continues up to now, and it forms a distinctive, unique and forward-looking art form through the support of modern technology.

Both fiber art and contemporary fiber art are widely used in the field of space decoration design. The material language and space decoration design of contemporary fiber art are combined with each other by the use of its material attributes, technology and unique creative combination, so that the artistic effect of space decoration has reached a higher level. However, contemporary fiber art is not a simple pile of various materials, but a combination of a certain characteristic of materials and many disciplines, changing its external characteristics and endowing new forms and connotations, so as to produce new visual effects. The most important thing is to give people pleasant enjoyment. ${ }^{2}$ At present, the positive transformation of decoration concept can not only

2. Yuan Min. Analysis of the Application of Contemporary Fiber Art Material Language in Art Creation [J]. Western Leather, 2018, 40 (07): 98 
make the space decoration design of modern fiber art more humane, more in line with the needs of people in the local and environment, but also accelerate the infinite potential of the space decoration design of contemporary fiber art. Contemporary fiber art is extending from the experience and display process of static materials to the all-around perception, including vision, hearing and touch. This variety of artistic expression is renewing people's cognition of fiber art.

\section{BUILDING THE SPACE IN THE FORM OF MATERIALS}

Traditional materials through the test of time are still in use today, it inevitably has its irreplaceable value. And color fiber in the earliest tapestry art, or in the development of the textile art, or of the fiber art, it is common and widely use of traditional materials. A lot of material and the texture of the material itself and easy dyeing sex, make the fiber materials and fiber art itself is easy to obtain and changeable, finally presents colorful effect. In this way, sight and touch constantly create a sense of freshness for people.

Because of the flexibility and variety of soft fiber materials, it's easier for them to intervene in different types of Spaces than other traditional materials, from the city to nature, from the interior of buildings to outdoor space, the ductility can be quickly and effectively occupy space, realize the idea of a creator, to create or build space. With the continuous discovery and application of color fiber, many artists in recent years use this material to create art, and convey to the audience the thoughts and emotions carried by the works. As early as 1942, Marcel Duchamp chose cotton cord as a soft, linear material for the exhibition hall design of a surrealist exhibition in New York. He takes up the entire space by pulling at random a mile of rope, connecting the space with the works in it until the whole environment looks like a giant spider's web. This "game work" is regarded as a necessary "seed" for contemporary fiber art. The creation foreshadows several very important characteristics: extension and occupation, intervention and interaction, field specificity and temporality. In fact, it is these elements that inspire the possibility of fiber art in the contemporary public sphere.

Since then, there have been more and more artists who build Spaces with fibers. Among them, Toshiko Horiuchi MacAdam, an artist who takes weaving as her creation technique, tries to use soft colored fiber materials to intervene in public space and construct independent space works. One of the most representative examples of Horiuchi's largescale interactive weaving art is the giant mesh space she created in 2012 with colored threads. Her work "Rainbow Net" is famous for its bright colors, vivid and interesting. More special is that each of her masterpieces can become adults and children's play tools, lively the whole space environment. The participation and laughter of the children bring the original motionless work to life. Horiuchi once said: "Why not make a colorful children's playground, and let the cheerful children become the most beautiful piece of my work?" Eventually, her works also become the children of rainbow kingdom.

Chinese "Cihai" interprets lines in traditional Chinese characters: Refers to the physical state of the line, with two or more than two single cotton or silk one or more of the merger or add sticky; Another way of saying it is to refer to something immaterial, long and thin, like a thread, like light, which is a metaphor for subtlety. This illustrates the connection between thread and weaving. 3 In contrast to giant woven works of art, there are artists who use lines as basic units to recreate the space. The representative artist Gabriel Dawe, who directly uses lines to build new Spaces, shows this artistic expression form incisively and vividly. With the concept that "line is the best element for building", he used two wooden strips to frame lines of different colors to create the light and shadow of the rainbow. Breadth (No. 19) is he in Italy a historical building work. Colored cotton threads are arranged in an orderly way between the balconies on the two floors of the building's atrium, forming two independent linear spatial structures. This colored-line installation uses subtle light to create a dazzling rainbow that blends in with the early 19th century neoclassical building, creating a rainbow space where a magnificent modern style meets classical art. Gabriel Dawe's fiber art explores the use of light as a symbolic language, What appears to be an invisible rainbow from a distance is an orderly phenomenon close up, revealing how our daily lives are governed by wonderful laws of nature. The whole and the parts of anything are exquisitely related.

In addition to creating with common textile materials, artists will also further try and explore the application of new materials. In addition to creating with common textile materials, artists also

3. Ci Hai, edited by Ci Hai Editorial Board, Shanghai: Shanghai Dictionary Publishing House, 1980, p. 1158. 
made further attempts and explorations on the application of new materials. Among them, the American artist Janet Echelman, known as the "innovator" of architectural compilation, assisted the artistic creation with technology, she turned the old traditional knitting techniques into a software program and applied them to Spectral fibers. It is light and flexible, but 15 times stronger than steel, unlike traditional textile materials such as cotton and linen. Janet Ecelman has used the new material to create huge colored mesh floating works over many cities, this series of works is made up of layers of fibers, Janet Echelman combines ancient fishing weaving with cutting edge technology, with bright materials woven and knot, the final presentation is in the audience's view. The work pulsates in the outdoor space with the change of the weather, slowly creating an undulating choreography of color in a form of eternal change. Different from the daytime, the large-scale fiber art installation of "Sky Fishing Net" in the night becomes more lifelike under the projected light, just like the net cast in the bottomless sea at night, drifting in the boundless sea.

Art comes from life and naturally interacts with people in daily life, not away from it. Janet Echelman's art works do just that. She once said in an interview, "I want to create a kind of appeal to listen to the heart through art, and connect with people in the public space, so that art can be a kind of flexible element existing in the busy urban life." In fact, this is her creative goal, and she has created a series of giant "fishing nets in the air" works to confirm her claim.

\section{BUILDING SPACE WITH TECHNOLOGY AS SUPPORT}

Due to the integration of contemporary fiber art with other disciplines and the addition of technology, the creation and expression of contemporary fiber art has changed from single to diverse due to the abundant materials and the support of technology. It adds an immersive art form that appears extensively in the spatial environment and changes the spatial environment. Immersive interaction means that the audience can have behavioral interaction and immersive feeling in the constructed space, so that the audience's feelings and behaviors become the important elements of the space and meaning expression of the work.

A series of techniques, such as the combination of space, the extension of space, the compression of space, and the mutual transformation of virtual and real space, are all used by artists to express their works. The transformation and combination of space increase the interest and participation of space. ${ }^{4}$ As Roy Ascot said, "The power of interactive art discourse lies in the artist leaving the creation of content to the experiencer of the work". ${ }^{5}$ In the interactive participation, visitors in the traditional sense are not only the appreciators and recipients of the works, but also the participants and creators of the works. The four giant flowers in Jerusalem's Vallero Square are part of an art installation by HQ Architects designed by the local government to improve the city's space. The most extraordinary thing about this flower is that it changes as the outside world changes, a flower that seems to fade on ordinary days blooms when cars and people pass by and stop by, such a living, the dynamic design of life comes from the sensor set in the flower of the work. In addition to giving the city a different look, it can actually shade the sun and keep out the rain. When the equipment is lit at night, it is not only practical, but also brings a completely different atmosphere.

Sensor device has been very common in contemporary fiber art. However, when a contemporary art work uses technology to achieve the effect, it is not completed by a single technology, but by the interlocking support of multiple technologies to complete the perfect artistic creation. Similar to the principles designed in HQ Architects' interactive floral street lamps, "the Daedalum Labyrinth" by Alan Parkinson uses an interactive inflatable art installation and lighting installation. Immersion inflatable maze is composed of special-shaped aeration device connected, using all kinds of different colors of translucent materials, to create a variety of space is full of light. The colors inside the maze change with the weather and light outside, bringing visitors to an amazing world of light, color and sound. More and more contemporary fiber art creates various combination of interactive installation elements in architectural space, which stimulates the visual, auditory, tactile and other multidimensional senses. The space atmosphere created by it deepens the viewer's sense of immersion.

\footnotetext{
4. Ma Jun. Discussion on Space Creation in Immersive Installation Art Experience [J]. Art Grand View, 2020 (22): 137138.

5. Roy Ascott, The Future Is Now: Art, Technology, and Consciousness [M], translated by Zhou Ling and Ren Aidan, Beijing: Jincheng Publishing House, 2012, p. 199.
} 
As the carrier of people's spiritual culture in public space, fiber installation art really creates a "soft environment" atmosphere for people in real life, making public space vivid and lively. Contemporary fiber art uses materials and technology to form material installation art, which makes use of the public space environment as a display property and gives full play to its own advantages. Fiber art installations provide a more humanized visual experience no matter in terms of material, form or color. At the same time, fiber installation art in public space embodies its unique artistic value. Fibre installation art and public space complement and complement each other. ${ }^{6}$ The creation of contemporary fiber installation art is influenced by the cultural attribute of public space, the way of space expression, the function and use of space, the style and scale of space, etc. This makes the relationship between fiber installation art and public space more close and harmonious.

\section{CONTEMPORARY FIBER ART AND SPACE RE-CREATION}

With the progress of modern science and technology, man's ability to transform nature has been enhanced unprecedentedly. We began to transform all natural objects and bring all things into the objective category. The diversified space construction of contemporary fiber art enables the viewer to obtain a multi-sensory and immersive aesthetic experience, but the purpose of artistic creation is not limited to this. The British art historian Ernst Gombrich believed: "The whole history of art development is not a history of technical proficiency, but a history of changes in ideas and requirements."7 The fundamental driving force and ultimate goal of artists' creation is still to express their thoughts on natural phenomena, humanities and social sciences. The remarkable advantages of fiber art, such as economy, easy handling and disassembly, recyclability and convenient processing, are exactly in line with the concepts and popular trends that are advocated today. Compared to hardclad materials, fiber art provides us with a wider range of choices, which is very important for a more reasonable and healthy sustainable development of the space.

6. Jiang Queen. Study on the Application of Ecoenvironmental Materials in Installation Art. The South China University of Technology. 2012, (5)

7. [British] Ernst Gombrich, The Story of Art [M], translated by Fan Jingzhong, Tianjin: Tianjin Fine Arts Publishing House, 1998, pp. 167-168.

\section{CONCLUSION}

On the basis of the traditional art form, science and technology and the combination of traditional art shows unknown mystery and surprise. Traditional art makes clever use of science and technology while retaining the essence, which gives the finishing touch to artistic creation. Contemporary fiber art is the product of fiber art in the traditional sense of continuous discovery of material, material application and technology integration. In the long history, people continue to explore and innovate. Therefore, fiber art not only precipitates the cultural deposits of ancient textile art, but also has the spirit of exploration combined with science and technology, which is full of vitality. The exploration, research and practice of material and technology in the creation of fiber art has practically broadened the extension space of fiber art.

\section{AUTHORS' CONTRIBUTIONS}

This paper is independently completed by Guangyu Luo.

\section{REFERENCES}

[1] Zhao Na. Analysis of the Innovation of Contemporary Fiber Art Design Language [J]. Art Research, 2019 (06): 132-133.

[2] Yuan Min. Analysis of the Application of Contemporary Fiber Art Material Language in Art Creation [J]. Western Leather, 2018,40 (07): 98

[3] Ci Hai, edited by Ci Hai Editorial Board, Shanghai: Shanghai Dictionary Publishing House, 1980, p. 1158.

[4] Ma Jun.Discussion on Space Creation in Immersive Installation Art Experience [J].Art Grand View, 2020 (22): 137-138.

[5] Roy Ascott, The Future Is Now: Art, Technology, and Consciousness [M], translated by Zhou Ling and Ren Aidan, Beijing: Jincheng Publishing House, 2012, p. 199.

[6] Jiang Queen. Study on the Application of Ecoenvironmental Materials in Installation Art. The South China University of Technology. 2012, (5) 
[7] [British] Ernst Gombrich, The Story of Art [M], translated by Fan Jingzhong, Tianjin: Tianjin Fine Arts Publishing House, 1998, pp. 167-168. 